Polish Journal of Microbiology

2016, Vol. 65, No 2, 201-207

ORIGINAL PAPER

\title{
Prevalence of Parasitic Contamination in Salad Vegetables Collected from Supermarkets and Street Vendors in Amman and Baqa'a - Jordan
}

\author{
YAZAN ISMAIL ${ }^{1 *}$ \\ ${ }^{1}$ Department of Allied Medical Sciences, Zarqa University College \\ Al-Balqa’ Applied University, Zarqa, Jordan
}

Submitted 8 September 2015, accepted 30 November 2015

\begin{abstract}
One of the main ways in transmitting parasites to humans is through consuming contaminated raw vegetables. The aim of this study was to evaluate the prevalence of parasitological contamination (helminthes eggs, Giardia and Entamoeba histolytica cysts) of salad vegetables sold at supermarkets and street vendors in Amman and Baqaa - Jordan. A total of 133 samples of salad vegetables were collected and examined for the prevalence of parasites. It was found that $29 \%$ of the samples were contaminated with different parasites. Of the 30 lettuce, 33 tomato, 42 parsley and 28 cucumber samples examined the prevalence of Ascaris spp. eggs was 43\%, 15\%, 21\% and 4\%; Toxocara spp. eggs was 30\%, 0\%, 0\% and 4\%; Giardia spp. cysts was 23\%, 6\%, $0 \%$ and $0 \%$; Taenia/Echinococcus eggs was 20\%, 0\%, 5\% and 0\%; Fasciola hepatica eggs was $13 \%, 3 \%, 2 \%$ and $0 \%$; and E. histolytica cysts was $10 \%, 6 \%, 0 \%$ and $0 \%$, respectively. There was no significant difference in the prevalence of parasite in salad vegetables either between supermarkets and street vendors, or between Amman and Baqa'a, Ascaris spp. was found to be the highest prevalent parasite in salad vegetables from supermarkets and street vendors and from Amman and Baqaa. Our results pointed out that, the parasitic contamination of salad vegetables found in our study might be caused by irrigating crops with faecal contaminated water. We concluded that salad vegetables sold in Amman and Baqaa may cause a health risk to consumers.
\end{abstract}

Ke y words: Amman, Baqa’a refugee camp, contamination, parasite, salad vegetable

\section{Introduction}

Foodborne disease causes diarrhoea, diarrhoea was reported by the world health organization to be one of the five most common disease causes of death in the world (1.6 million deaths per year) (Baldursson and Karanis, 2011). Foodborne disease could be caused by viruses, bacteria and parasites, while transmission can occur by contaminated food such as contaminated vegetables. Vegetables can become contaminated during growth, harvesting, processing and distribution (Slifko et al., 2000; Dawson, 2005). The sources of vegetable parasite contamination during growth are sewage sludge, untreated waste water, contaminated slurry, farm livestock, and indigenous wildlife (Slifko et al., 2000; Lanata, 2003; Dawson, 2005).

Parasites (protozoa or helminthes) could be transmitted to humans by ingesting one of the parasite environmental transmission stages (protozoa: cysts and oocytes, helminthes: eggs, and larval) (Slifko et al., 2000; WHO, 2003). Consuming improperly washed vege- tables such as salad vegetables represent one of the major forms in transmitting parasites into humans, in which raw vegetables play a role as a vehicle in the parasite transportation. The prevalence of parasites in vegetables was reported in many developed and developing countries (da Silva et al., 1995; Robertson and Gjerde, 2000; 2001; Al-Binali et al., 2006; Daryani et al., 2008; Uga et al., 2009; Abougrain et al., 2010; Al-Megrm, 2010; Iournals, 2014).

Jordan is a small Middle Eastern country with limited natural resources. Jordan water resources is one of the lowest in the world, the renewable fresh water resources is approximately $135 \mathrm{~m}^{3}$ per capita for all uses and $90 \%$ of the country receive annual precipitation less than $200 \mathrm{~mm}$ (Raddad, 2005; Al-Jaloudy, 2006). Jordan population was estimated at 6.3 million in 2012 as reported by the Jordanian department of statistics (DSJ, 2014). Vegetables are one of the major components of the daily diet in Jordan, from which vegetable salad (cucumber, tomato, lettuce and parsley) being one of the daily dishes. The main parasites detected in

* Corresponding author: Y. Ismail, School of Allied Medical Sciences, Zarqa University College P.O. Box 313, Al-Balqa’ Applied University, Jordan; e-mail: yazan_al_wedyan@hotmail.com or y.ismail@bau.edu.jo 
vegetables in the neighbouring countries were Ascaris spp., Taenia spp., Fasciola spp., Toxocara spp., Echinococcus spp., Giardia spp. and Entamoeba histolytica (Sharif, 2002; Al-Shawa and Mwafy, 2007; Hadi, 2011; Hassan et al., 2012; Adanir and Tasci, 2013; Ali and Ameen, 2013). To our knowledge, no published study to date has evaluated the parasitological contamination of salad vegetables sold at Jordanian markets. Therefore, the aim of this study was to evaluate the prevalence of parasitological contamination (helminthes eggs, Giardia and E. histolytica cysts) of salad vegetables at supermarkets and street vendors in Amman and Baqa’a - Jordan.

\section{Experimental}

\section{Materials and Methods}

The study area. Samples were collected from different areas in Amman and Baqa'a. Amman is the capital city of Jordan, with a population of almost 2.5 million inhabitants (39\% of Jordan population) (DSJ, 2014). Amman is situated in the mountain heights plateau of Jordan with an elevation ranging from 400 to $1000 \mathrm{~m}$ above sea level (Al Rawashdeh and Saleh, 2006), Amman has a mediterranean climate; moderate and dry in summer (average temperature $25^{\circ} \mathrm{C}$ ) cold and wet in winter (average temperature $9^{\circ} \mathrm{C}$ ) (JOMETEO, 2015) with an annual rainfall of almost $500 \mathrm{~mm}$ (Dahamsheh and Aksoy, 2007).

Baqa'a is the largest Palestinian refugee camp in Jordan with more than 100.000 registered refugees. Baqa'a is situated almost $20 \mathrm{~km}$ north of Amman (UNRWA, 2015) with a similar climate to Amman. Baqa'a refugee camp has a higher poverty and a poorer environmental hygiene compared to Amman (UNRWA, 2015).

Sampling. A total of 133 samples of salad vegetables were collected from supermarkets and street vendors in Amman and Baqa'a as shown in Table I. Salad vegetables were collected randomly between March 2014 and August 2014.

Table I

Number of samples collected from each area

\begin{tabular}{|l|c|c|c|c|c|}
\hline \multirow{7}{*}{ Total } & \multicolumn{2}{|c|}{$\begin{array}{c}\text { Number of samples } \\
\text { collected } \\
\text { from Amman }\end{array}$} & \multicolumn{2}{|c|}{$\begin{array}{c}\text { Number of samples } \\
\text { collected } \\
\text { from Baqa' }\end{array}$} & \multirow{2}{*}{ Total } \\
\cline { 2 - 5 } & $\begin{array}{c}\text { Super- } \\
\text { market }\end{array}$ & $\begin{array}{c}\text { Street } \\
\text { vendors }\end{array}$ & $\begin{array}{c}\text { Super- } \\
\text { market }\end{array}$ & $\begin{array}{c}\text { Street } \\
\text { vendors }\end{array}$ & \\
\hline Lettuce & 8 & 8 & 7 & 7 & 30 \\
\hline Tomato & 7 & 8 & 10 & 8 & 33 \\
\hline Parsley & 10 & 9 & 11 & 12 & 42 \\
\hline Cucumber & 7 & 7 & 7 & 7 & 28 \\
\hline
\end{tabular}

Determination of intestinal parasites. Each sample was weighed $(250 \mathrm{~g})$ and placed into sterile plastic bags, samples were then washed with one litter of sterile normal saline solution $(0.85 \% \mathrm{NaCl})$ by shacking for 20 minutes. The washing saline was then left to sediment overnight. The supernatant was discarded and the remaining washing saline $(50 \mathrm{ml})$ was centrifuged at 2000 RCF for 15 minutes. Supernatant was then discarded and the remaining pellet with $5 \mathrm{ml}$ of the saline was collected (Erdoğrul and Şener, 2005). Three simple and three iodine stained smears were then prepared from each sample, smears were used to detect helminthes eggs, Giardia and E. histolytica cysts using light microscope (Downes and Ito, 2001).

Statistical analysis. Fisher's exact test was used to assess the differences between proportions, significance was defined as $P<0.05$. The analyses were made using GraphPad Prism 5 software (San Diego, CA).

\section{Results}

A total of 133 samples of salad vegetables (30 lettuces, 33 tomatoes, 42 parsley and 28 cucumbers; Table I) were examined for the presence of parasites (helminthes eggs, Giardia and E. histolytica cysts). It was found that $29 \%$ (39 out of 133) of the salad vegetable samples were contaminated with different parasites (helminthes eggs, Giardia and E. histolytica cysts). The highest percentage of contamination was detected in lettuce samples (63\%), while tomato and parsley samples showed lower contamination percentage ( $27 \%$ and $24 \%$, respectively). The least percentage of contamination was detected in cucumber (13\%). Lettuce samples were contaminated significantly more often than tomato, parsley and cucumber with parasites $(P=0.006$, Odds ratio $=4.6 ; P=0.001$, Odds ratio $=5.5$ and $P<0.0001$, Odds ratio $=46.6$, respectively), further details are shown in Table II.

Twenty seven percent (18 out of 67) of salad vegetable samples sold at supermarkets and 32\% (21 out of 66) of salad vegetable samples sold at street vendors were contaminated with different parasites (Table II), no significant difference was found between the prevalence of parasites in salad vegetables sold at supermarkets and street vendors $(P>0.05$, Table II). Ascaris spp. was found to be the highest prevalent parasite in salad vegetables sold at supermarkets and street vendors (18\% and $24 \%$, respectively; Table III).

The prevalence of Ascaris spp. eggs found in the 30 lettuce, 33 tomato, 42 parsley and 28 cucumber samples examined was $43 \%, 15 \%, 21 \%$ and $4 \%$, respectively. Ascaris spp. eggs was found to be significantly higher in total lettuce samples than in total tomato and cucumber samples $(P=0.024$, Odds ratio $=4.2$ and 
Table II

Prevalence of parasites in salad vegetables according to area, retail and vegetable type

\begin{tabular}{|l|c|c|c|c|c|}
\hline \multirow{2}{*}{} & \multicolumn{2}{|c|}{ Parasite contamination\% Amman } & \multicolumn{2}{c|}{ Parasite contamination\% Baqaá } & \multirow{2}{*}{$\begin{array}{c}\text { Total Parasite } \\
\text { contamination }\end{array}$} \\
\cline { 2 - 5 } & $\begin{array}{c}\text { Supermarket } \\
\%(\text { No.) }\end{array}$ & $\begin{array}{c}\text { Street vendors } \\
\%(\text { No. })\end{array}$ & $\begin{array}{c}\text { Supermarket } \\
\%(\text { No. })\end{array}$ & $\begin{array}{c}\text { Street vendors } \\
\%(\text { No.) }\end{array}$ & \\
\hline Lettuce & $62.5 \%(5$ out of 8$)$ & $75 \%(6$ out of 8$)$ & $42.9 \%(3$ out of 7$)$ & $71.4(5$ out of 7$)$ & $63.3 \%(19 \text { out of } 30)^{\mathrm{b}}$ \\
\hline Tomato & $14.3 \%(1$ out of 7$)$ & $25 \%(2$ out of 8$)$ & $40 \%(4$ out of 10$)$ & $25 \%(2$ out of 8$)$ & $27.3 \%(9 \text { out of } 33)^{\mathrm{c}}$ \\
\hline Parsley & $10 \%(1$ out of 10$)$ & $44.4 \%(4$ out of 9$)$ & $27.3 \%(3$ out of 11$)$ & $16.7 \%(2$ out of 12$)$ & $23.8 \%(10 \text { out of } 42)^{\mathrm{d}}$ \\
\hline Cucumber & $14.3 \%(1$ out of 7$)$ & $0 \%(0$ out of 7$)$ & $0 \%(0$ out of 7$)$ & $0 \%(0$ out of 7$)$ & $3.6 \%(1$ out of 28$)$ \\
\hline Total salad vegetables & $25 \%(8$ out of 32$)$ & $37.5 \%(12$ out of 32$)$ & $28.6 \%(10$ out of 35$)$ & $26.5 \%(9$ out of 34$)$ & $29.3(39$ out of 133$)$ \\
\hline
\end{tabular}

Note: $26.9 \%$ (18 out of 67 ) of salad vegetable samples sold at supermarkets were contaminated with parasites and $31.8 \%(21$ out of 66$)$ of salad vegetable samples sold at street vendors were contaminated with different parasites (no significant difference between the two ways of retail, $P>0.05$ ). ${ }^{a}$ No.: number of contaminated samples out of the total sample number.

${ }^{b}$ Lettuce samples were contaminated significantly more often than tomato, parsley and cucumber samples with parasites $(\mathrm{P}=0.006, \mathrm{Odds}$ ratio $=4.6$; $\mathrm{P}=0.001$, Odd ratio $=5.5$ and $\mathrm{P}<0.0001$, Odds ratio $=46.6$, respectively).

${ }^{c}$ Tomato samples were contaminated significantly more often than cucumber samples with parasites $(\mathrm{P}=0.016$, Odds ratio $=10.1)$.

${ }^{d}$ Parsley samples were contaminated significantly more often than cucumber samples with parasites $(\mathrm{P}=0.041$, Odds ratio $=8.4)$.

Table III

Prevalence of different parasites detected in salad vegetables from supermarkets and street vendors

\begin{tabular}{|l|l|c|c|c|c|c|c|}
\hline Vegetables & \multicolumn{1}{|c|}{ Source } & $\begin{array}{c}\text { Ascaris spp. } \\
\text { No. }(\%)\end{array}$ & $\begin{array}{c}\text { Toxocara spp. } \\
\text { No. }(\%)\end{array}$ & $\begin{array}{c}\text { Giardia spp. } \\
\text { No. }(\%)\end{array}$ & $\begin{array}{c}\text { Taenial } \\
\text { Echinococcus } \\
\text { No. }(\%)\end{array}$ & $\begin{array}{c}\text { Fasciola spp. } \\
\text { No. (\%) }\end{array}$ & $\begin{array}{c}\text { Entamoeba } \\
\text { histolytica } \\
\text { No. (\%) }\end{array}$ \\
\hline Lettuce & Supermarkets $\mathrm{n}=15$ & $5(33.3)^{\mathrm{a}}$ & $4(26.7)$ & $2(13.3)$ & $2(13.3)$ & $1(6.7)$ & $0(0)$ \\
\hline & Street vendors $\mathrm{n}=15$ & $8(53.3)^{\mathrm{b}}$ & $5(33.3)$ & $5(33.3)$ & $4(26.7)$ & $3(20)$ & $3(20)$ \\
\hline & Total $\mathrm{n}=30$ & $13(43.3)^{\mathrm{c}}$ & $9(30)^{\mathrm{e}}$ & $7(23.3)^{\mathrm{f}}$ & $6(20.0)^{\mathrm{g}}$ & $4(13.3)$ & $3(10)$ \\
\hline Tomato & Supermarkets $\mathrm{n}=17$ & $3(17.6)$ & $0(0)$ & $1(5.9)$ & $0(0)$ & $0(0)$ & $2(11.8)$ \\
\hline & Street vendors $\mathrm{n}=16$ & $2(12.5)$ & $0(0)$ & $1(6.3)$ & $0(0)$ & $1(6.3)$ & $0(0)$ \\
\hline & Total $\mathrm{n}=33$ & $5(15.2)$ & $0(0)$ & $2(6.1)$ & $0(0)$ & $1(3.0)$ & $2(6.1)$ \\
\hline & Supermarkets $\mathrm{n}=21$ & $3(14.3)$ & $0(0)$ & $0(0)$ & $1(4.8)$ & $0(0)$ & $0(0)$ \\
\hline & Street vendors $\mathrm{n}=21$ & $6(28.6)$ & $0(0)$ & $0(0)$ & $1(4.8)$ & $1(4.8)$ & $0(0)$ \\
\hline & Total $\mathrm{n}=42$ & $9(21.4)^{\mathrm{d}}$ & $0(0)$ & $0(0)$ & $2(4.8)$ & $1(2.4)$ & $0(0)$ \\
\hline & Supermarkets $\mathrm{n}=14$ & $1(7.1)$ & $1(7.1)$ & $0(0)$ & $0(0)$ & $0(0)$ & $0(0)$ \\
\hline & Street vendors $\mathrm{n}=14$ & $0(0)$ & $0(0)$ & $0(0)$ & $0(0)$ & $0(0)$ & $0(0)$ \\
\hline & Total $\mathrm{n}=28$ & $1(3.6)$ & $1(3.6)$ & $0(0)$ & $0(0)$ & $0(0)$ & $0(0)$ \\
\hline & Supermarkets $\mathrm{n}=67$ & $12(17.9)$ & $5(7.5)$ & $3(4.5)$ & $3(4.5)$ & $1(1.5)$ & $2(3.0)$ \\
\hline & Street vendors $\mathrm{n}=66$ & $16(24.2)$ & $5(7.6)$ & $6(9.1)$ & $5(7.6)$ & $5(7.6)$ & $3(4.5)$ \\
\hline & Total $\mathrm{n}=133$ & $28(21.1)$ & $10(7.5)$ & $9(6.8)$ & $8(6.0)$ & $6(4.5)$ & $5(3.8)$ \\
\hline
\end{tabular}

a The highest prevalent pathogenic intestinal parasite found in supermarkets was Ascaris spp.

${ }^{\mathrm{b}}$ The highest prevalent pathogenic intestinal parasite found in street vendors was Ascaris spp.

${ }^{c}$ The prevalence of Ascaris spp. eggs was significantly higher in total lettuce samples than in total tomato and cucumber samples

$(P=0.024$, Odds ratio $=4.2$ and $P=0.0005$, Odds ratio $=20.7$, respectively $)$.

d The prevalence of Ascaris spp. eggs was significantly higher in total parsley samples than in total cucumber samples $(P=0.042$, Odds ratio $=7.4)$.

e The prevalence of Toxocara spp. eggs was significantly higher in total lettuce samples than in total tomato, parsley and cucumber samples

$(P=0.0006$, Odds ratio $=29.6 ; P=0.0002$, Odds ratio $=37.6$ and $P=0.013$, Odds ratio $=11.6$, respectively $)$.

${ }^{f}$ The prevalence of Giardia spp. cysts was significantly higher in total lettuce samples than in total parsley and cucumber samples $(P=0.0014$, Odds ratio $=27.1$ and $P=0.011$, Odds ratio $=18.2$, respectively).

${ }^{g}$ The prevalence of Taenia/Echinococcus eggs was significantly higher in total lettuce samples than in total tomato and cucumber samples $(P=0.009$, Odds ratio $=17.8$ and $P=0.024$, Odds ratio $=15.1$, respectively $)$.

$P=0.0005$, Odds ratio $=20.7$, respectively), it was also found to be significantly higher in parsley samples than in total cucumber samples $(P=0.042$, Odds ratio $=7.4)$. Table III shows further details of the prevalence of parasites (helminthes eggs, Giardia and E. histolytica cysts) that have been detected in salad vegetable samples collected from supermarkets and street vendors.

Thirty one percent (20 out of 64) of salad vegetables samples sold in Amman and 28\% (19 out of 69) of salad vegetables samples sold in Baqa'a were contaminated 
Table IV

Prevalence of different parasites detected in salad vegetables from Amman and Baqa'a

\begin{tabular}{|l|c|c|}
\hline & $\begin{array}{c}\text { Vegetables sold } \\
\text { in Amman, } \\
\text { No. }(\%), \mathrm{n}=64\end{array}$ & $\begin{array}{c}\text { Vegetables sold } \\
\text { in Baqa', } \\
\text { No. }(\%), \mathrm{n}=69\end{array}$ \\
\hline Non-infected & $44(68.8)$ & $50(72.5)$ \\
\hline Infected & $20(31.2)$ & $19(27.5)$ \\
\hline Ascaris spp. & $14(21.8)^{\mathrm{a}}$ & $13(18.8)^{\mathrm{b}}$ \\
\hline Toxocara spp. & $5(7.8)$ & $5(7.2)$ \\
\hline Giardia spp. & $5(7.8)$ & $4(5.8)$ \\
\hline Taenia/Echinococcus & $5(7.8)$ & $2(2.9)$ \\
\hline Fasciola spp. & $2(3.1)$ & $4(5.8)$ \\
\hline Entamoeba histolytica & $3(4.7)$ & $2(2.9)$ \\
\hline
\end{tabular}

a The highest prevalent pathogenic intestinal parasite found in vegetables sold in Amman was Ascaris spp.

'The highest prevalent pathogenic intestinal parasite found in vegetables sold in Baqaa was Ascaris spp.

with different parasites (Table IV). No significant difference was found between the prevalence of parasites in salad vegetables sold at Amman and Baqa'a $(P>0.05)$. Ascaris spp. was found to be the highest prevalent parasite in salad vegetables at Amman and Baqaa areas (22\% and $19 \%$, respectively; Table III). Table IV shows further details of the prevalence of parasites that have been detected in salad vegetable samples collected from Amman and Baqa'a.

\section{Discussion}

Fresh vegetable could become contaminated by parasites while growing in the field through irrigation, soil or types of fertilizers used. Other sources of con- tamination include harvesting, distribution or the retail market (Beuchat, 2002).

When comparing the prevalence of parasites attached to salad vegetables in the neighbouring developing countries and the developed countries (Table V), it is clear that the prevalence is higher in neighbouring developing countries ranging from $16 \%$ to $58 \%$ (AlBinali et al., 2006; Al-Shawa and Mwafy, 2007; Daryani et al., 2008; Abougrain et al., 2010; Al-Megrm, 2010; Fallah et al., 2012; Hassan et al., 2012; Ali and Ameen, 2013) when compared to the prevalence in more developed countries like Turkey (Adanir and Tasci, 2013) and Norway (Robertson and Gjerde, 2001) (6\% for both countries). In our study, it was found that $29 \%$ of the 133 salad vegetables samples examined were contaminated with different parasites (helminthes eggs, Giardia and E. histolytica cysts). The similarity between the prevalence of parasites attached to salad vegetables found in our study and the neighbouring developing countries could reflect a common way of contamination. The previous studies (Al-Binali et al., 2006; Al-Shawa and Mwafy, 2007; Daryani et al., 2008; Abougrain et al., 2010; Al-Megrm, 2010; Hassan et al., 2012; Ali and Ameen, 2013) shared the finding that the main source of parasite contamination found in vegetables was from irrigating vegetables with faecal contaminated water.

High prevalence of transmitted helminthes and protozoa could be caused by poverty, poor environmental hygiene and poor sanitation (Montresor et al., 1998; Jamaiah and Rohela, 2005). In our study we compared the prevalence of parasites in salad vegetables sold in Amman and in Baqa'a refugee camp (31\% and 28\%, respectively). Unexpectedly, no significant difference was found in the prevalence of parasites in salad vegetables between these two areas. The study also compared the prevalence of parasites attached to salad vegetables

Table V

Prevalence of parasites in salad vegetables at different neighbouring developing countries and developed countries

\begin{tabular}{|l|c|l|}
\hline \multicolumn{1}{|c|}{ City } & $\begin{array}{c}\text { Prevalence of parasite } \\
\text { in examined salad vegetables } \\
\%(\text { No. })^{\text {a }}\end{array}$ & \multicolumn{1}{|c|}{ Reference } \\
\hline Tripoli - Libya & $57.9 \%(73$ out of 126$)$ & (Abougrain et al., 2010$)$ \\
\hline Ardabil - Iran & $56.7 \%(80$ out of 141$)$ & (Daryani et al., 2008$)$ \\
\hline Sulaimani - Iraq & $49.8 \%(119$ out of 239$)$ & (Ali and Ameen, 2013$)$ \\
\hline Gaza Governorates & $37.0 \%(80$ out of 216$)$ & (Al-Shawa and Mwafy, 2007) \\
\hline Shahrekord - Iran & $32.6 \%(99$ out of 304$)$ & (Fallah et al., 2012$)$ \\
\hline Abha - Saudi Arabia & $27.2 \%$ & (Al-Binali et al., 2006$)$ \\
\hline Alexandria - Egypt & $19.4 \%(19$ out of 98$)$ & (Hassan et al., 2012) \\
\hline Riyadh - Saudi Arabia & $16.2 \%(76$ out of 470$)$ & (Al-Megrm, 2010) \\
\hline Burdur - Turkey & $6.3 \%(7$ out of 111$)$ & (Adanir and Tasci, 2013) \\
\hline Norway & $6.1 \%(29$ out of 475$)$ & (Robertson and Gjerde, 2001) \\
\hline
\end{tabular}

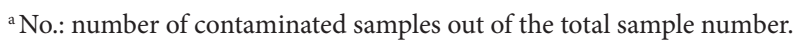


sold at supermarkets and street vendors (27\% and 32\%, respectively), yet again no significant difference in the prevalence of parasites in salad vegetables was found between these two modes of retail. These findings exclude poor environmental hygiene and poor sanitation of the marketing area or retail method as the main cause of salad vegetable contamination, and points to the vegetable field growing area as the main source of contamination.

In Tripoli - Libya Ascaris spp. eggs were reported to be the most predominant parasite attached to salad vegetables, the study reported that $68 \%$ of salad vegetables examined were contaminated with Ascaris spp. eggs (Abougrain et al., 2010). Ascaris spp. was also one of the most prevalent detected parasite attached to vegetables in the neighbouring developing countries ranging from $12 \%$ to $26 \%$ (Al-Shawa and Mwafy, 2007; Al-Megrm, 2010; Fallah et al., 2012; Ali and Ameen, 2013). In Jordan, a study by Al-Lahham et al. (1990) found that the highest intestinal parasite detected in the stool samples collected from 283 food handlers was Ascaris lumbricoides with a detection rate of $5 \%$. In our study the prevalence of Ascaris spp. eggs attached to vegetables was $21 \%$ and were found to be the highest detected parasite in salad vegetables examined, our findings agrees with the previous studies. This study did not differentiate between A. lumbricoides and Ascaris suum eggs as these two species eggs have a highly similar morphological appearance (Blaszkowska et al., 2011).

Lettuce and parsley leafs have a more rough surface texture and surface area when compared to tomato and cucumber surfaces making it a more easier area for attaching parasites, lettuce and parsley vegetable are also in more direct contact with soil and irrigating water than in tomato and cucumber vegetables. In the present study the prevalence of Ascaris spp. eggs was found to be significantly higher in lettuce samples (43\%) than in tomato (15\%) and cucumber (4\%) samples. Ascaris spp. eggs were also significantly higher in parsley samples $(21 \%)$ than in cucumber samples (4\%) and higher than in tomato (15\%) samples. Ascaris spp. is usually found in sewage and untreated waste water and is used as an indicator organism for sewage and water treatment process (Gerba and Smith, 2005). These findings may indicate that the soil that crops grow on and water used in irrigating crops are faecal contaminated.

The prevalence of Toxocara spp. attached to vegetables in some neighbouring developing countries ranged from 3\% to 18\% (Hadi, 2011; Fallah et al., 2012; Adanir and Tasci, 2013). In Jordan a study by Abo-Shehada (1989) found that $16 \%$ of soil samples collected from school playgrounds and public places were contaminated with Toxacara eggs. A serological survey conducted in north of Jordan by Abo-Shehada et al. (1992) showed a seroprevalence of Toxocara canis in $11 \%$ of tested individuals. In the present study Toxocara spp. eggs were detected in $10 \%$ of salad vegetables which agrees with the previous findings. According to our finding, consuming unwashed salad vegetables may cause Toxocariasis. This study did not differentiate between Toxacara cati and T.canis eggs as these two species eggs have a highly similar morphological appearance (Blaszkowska et al., 2011).

A study conducted in Jordan by El-Shehabi et al. (1999) detected T.canis in the intestines of $1.2 \%$ of dogs infected with intestinal helminths. In our study, the prevalence of Toxocara spp. eggs attached to lettuce was found to be $30 \%$ and significantly higher than the prevalence found in tomato $(0 \%)$, parsley $(0 \%)$ and cucumber (4\%) samples. As Toxocara spp. eggs are excreted by dogs and cats faeces (Deplazes et al., 2011), our finding indicate that lettuce is cultivated in an opened lands that are inhibited with more roaming dogs and cats when compared to parsley, tomato and cucumber cultivation lands.

Giardia cysts are found on surface water such as lakes and rivers, and their concentration is positively associated with the water pollution by means of residential or agricultural faecal contamination (Rosen et al., 2000; Karanis et al., 2006). The prevalence of Giardia spp. cysts attached to vegetables in some neighbouring developing countries ranged from $7 \%$ to $10 \%$ (Abougrain et al., 2010; Hassan et al., 2012; Ali and Ameen, 2013). In our study we detected the eggs of Giardia spp. in $9 \%$ of salad vegetables which agrees with the previous studies, our finding suggest that using faecal contaminated water for irrigation could be the main source of contamination of salad vegetables with Giardia spp.

Giardia lamblia causes giardiasis in humans, it is reported that ingesting as low as 10 Giardia cysts by humans may cause disease (Arnone and Walling, 2007). A study by Shakkoury and Wandy (2005) reported that the prevalance of G. lamblia in stool samples collected from individuals visiting primary health care centres in Amman - Jordan was $30 \%$. In our study, the prevalence of Giardia spp. cysts attached to lettuce was found to be $23 \%$ and significantly higher than the prevalence in parsley and cucumber samples (Giardia spp. was not detected in the parsley and cucumber samples). Our results indicate that the high prevalence of Giardia spp. in lettuce may pose a risk to consumer's health if unwashed prior to consumption.

The prevalence of Taenia spp. attached to vegetables in some neighbouring countries was $11 \%$ in Sulaimani - Iraq (Ali and Ameen, 2013) and 3\% in Burdur - Turkey (Adanir and Tasci, 2013). In our study we did not differentiate between the eggs of Taenia spp. and the eggs of Echinococcus spp. as they are undistinguishable from each other. The prevalence of Taenia/Echinococcus attached to vegetables in the present study was $6 \%$. 
The prevalence of Taenia spp. attached to leafy vegetables in Riyadh - Saudi Arabia was 20\% (Al-Megrm, 2010), and the prevalence of Taenia/Echinococcus attached to lettuce in Tripoli - Libya was 33\% (Abougrain et al., 2010). In Jordan, a study by Al-Lahham et al. (1990) detected Taenia saginata in $0.4 \%$ of the stool samples collected from 283 food handlers. In our study, the prevalence of Taenia/Echinococcus attached to lettuce was found to be $20 \%$ and significantly higher than the prevalence in tomato and cucumber samples (Taenia/Echinococcus were not detected in the tomato and cucumber samples). The high prevalence of Taenial Echinococcus in lettuce may pose a risk to consumer's health if unwashed prior to consumption. In Jordan the annual incidence of hydatidosis (a human disease caused by Echinococcus granulosus) depending on the region was found to be 15-65 per 100.000 (Kamhawi and Hijawi, 1992).

A study by Ajlouni et al. in 1984 found that $14 \%$ of stray dogs in Jordan were infected with E. granulosus (Ajlouni et al., 1984) and a study by Maraqa et al. (2005) reported that $20 \%$ of Jordan local sheep were infected with E. granulosus. As Echinococcus spp. eggs are excreted by dogs and sheep faeces (Deplazes et al., 2011), our finding indicate that lettuce is cultivated in open lands that are inhabited with more roaming dogs or sheep when compared to tomato and cucumber cultivation lands.

The prevalence of Fasciola spp. attached to vegetables in some neighbouring developing countries was $21 \%$ in Sulaimani - Iraq (Ali and Ameen, 2013) and 15\% in Riyadh - Saudi Arabia (Al-Megrm, 2010). A study by Maraqa et al. (2005) reported that 3.2\% of the sheep imported to Jordan from Romania were infected with Fasciola hepatica and a study by Sharrif et al. (1998) found that the prevalance rate of F. hepatica in camels grown in Jordan was $4 \%$. In our study we detected the eggs of Fasciola spp. in 5\% of salad vegetables.

The prevalence of E. histolytica attached to vegetables in some neighbouring developing countries ranged from 7\% to 38\% (Al-Shawa and Mwafy, 2007; Hassan et al., 2012; Ali and Ameen, 2013). A study in Amman - Jordan by Al-Momani et al. (2006) detected E. histolytica in $20 \%$ of the positive parasite stool samples. Another study in Amman - Jordan by Chazal and Adi (2007) found that E. histolytica as the most prevalent parasite detected in stool samples, with an infection rate of $28 \%$. In our study we detected the cysts of E. histolytica in $4 \%$ of salad vegetables and the highest prevalence was found in lettuce samples (10\%). Our results indicate that, the high prevalence of E. histolytica in salad vegetables especially in lettuce may pose a risk to consumer's health, if unwashed prior to consumption. The presence of E. histolytica in salad vegetables indicates that salad vegetables are faecal contaminated.
Our results point out that, the most probable source of the parasite contamination found in salad vegetables sold at Amman and Baqaa is from using faecal contaminated water in irrigating crops. It seems that the scarceness of fresh water in Jordan has pushed farmers to use faecal contaminated water in irrigating their crops. So, action is needed to direct farmers to use treated wastewater in irrigating trees or vegetable crops that is not intended to be eaten row, educating farmers on the risk of using faecal contaminated water for irrigation on the public health and perform a proper treatment of sewage water. In order to confirm the source of parasite contamination found in salad vegetable, further studies is needed to examine the salad vegetables cultivation area and to examine the water sources used in irrigation.

Our study showed that salad vegetables sold in Amman and Baqaa are contaminated with parasites (helminthes eggs, Giardia and E. histolytica cysts) that may cause health risk to consumers. So, programs in the essentiality of washing raw vegetables prior to consumption and personal hygiene must be intensified.

\section{Acknowledgements}

I am grateful to Mauz Al-Zouby and Lena Alardah for helping me all through the research, I thank the laboratory staff Eman Abuhamra and Husam Arar for their contribution in preparing the media and sample collection. I also thank prof. Mohammed Al-Shatnawi, Dr. Bassam El-eswed and Dr. Qasem Abu Shaqra for reviewing the manuscript.

\section{Literature}

Abo-Shehada M., L. Sharif, S.N. el-Sukhon, N. Abuharfeil and R.F. Atmeh. 1992. Seroprevalence of Toxocara canis antibodies in humans in northern Jordan. J. Helminthol. 66(1): 75-78.

Abo-Shehada M.N. 1989. Prevalence of Toxocara ova in some schools and public grounds in northern and central Jordan. Ann. Trop. Med. Parasitol. 83(1): 73-75.

Abougrain A.K., M.H. Nahaisi, N.S. Madi, M.M. Saied and K.S. Ghenghesh. 2010. Parasitological contamination in salad vegetables in Tripoli-Libya. Food Control. 21: 760-762.

Adanir R. and F. Tasci. 2013. Prevalence of helminth eggs in raw vegetables consumed in Burdur, Turkey. Food Control. 31: 482-484. Ajlouni A.Q., E.K. Saliba and A.M. Disi. 1984. Intestinal cestodes of stray dogs in Jordan. Z. Parasitenkunde 70: 203-210.

Al-Binali A.M., C.S. Bello, K. El-Shewy and S.E. Abdulla. 2006. The prevalence of parasites in commonly used leafy vegetables in South Western, Saudi Arabia. Saudi Med. J. 27(5): 613-616.

Ali S.A. and H.A. Ameen. 2013. Prevalence of human intestinal parasites in selected vegetables in Sulaimani City. JSMC 3: 75-79.

Al-Jaloudy M.A. 2006. Country pasture/forage resource profiles. Ministry of Agriculture. Amman.

Al-Lahham A.B., M. Abu-Saud and A. Shehabi. 1990. Prevalence of Salmonella, Shigella and intestinal parasites in food handlers in Irbid, Jordan. J. Diarrhoeal. Dis. Res. 8(4): 160-162.

Al-Megrm W.I. 2010. Prevalence of intestinal parasites in leafy vegetables in Riyadh, Saudi Arabia. IJT Med. 6: 137-142. 
Al-Momani T., M.B. Jabber, H. Abdallat and M. Abbadi. 2006 Frequency of intestinal parasites at princess Aysha medical complex, Marka, Jordan. JRMS 13: 70-73.

Al Rawashdeh S. and B. Saleh. 2006. Satellite monitoring of urban spatial growth in the Amman area, Jordan. J. Urban Plan. and Develop.132: 211-216.

Al-Shawa R.M. and S.N. Mwafy. 2007. The enteroparasitic contamination of commercial vegetables in Gaza Governorates. J. Infect. Dev. Countries 1: 62-66.

Arnone R. and J. Walling. 2007. Waterborne pathogens in urban watersheds. J. Water Health 5: 149-162.

Baldursson S. and P. Karanis. 2011. Waterborne transmission of protozoan parasites: review of worldwide outbreaks - an update 2004-2010. Water Res. 45: 6603-6614.

Beuchat L.R. 2002. Ecological factors influencing survival and growth of human pathogens on raw fruits and vegetables. Microbes Infect. 4: 413-423.

Blaszkowska J., P. Kurnatowski and P. Damiecka. 2011. Contamination of the soil by eggs of geohelminths in rural areas of Lodz district (Poland). Helminthologia 48: 67-76.

Chazal A. and H. Adi. 2007. The prevalence of intestinal parasites in Amman, Jordan. Bulletin of Pharmaceutical Sciences-Assiut University 30: 235-239.

da Silva J.P., M.C. Marzochi, L. Camillo-Coura, A. Messias Ade and S. Marques. 1995. Intestinal parasite contamination of vegetables sold at supermarkets in the city of Rio de Janeiro. Revista da Sociedade Brasileira de Medicina Tropical 28: 237-241.

Dahamsheh A. and H. Aksoy. 2007. Structural characteristics of annual precipitation data in Jordan. Theor. App. Climat. 88: 201-212. Daryani A., G. Ettehad, M. Sharif, L. Ghorbani and H. Ziaei. 2008 Prevalence of intestinal parasites in vegetables consumed in Ardabil, Iran. Food Control 19: 790-794.

Dawson D. 2005. Foodborne protozoan parasites. Int. J. Food Microbial. 103: 207-227.

Department of Statistics-Jordan (DSJ). 2014. Jordan statistical yearbook 2013. http://www.dos.gov.jo/dos_home_a/main/yearbook_ 2013.pdf, 2015.04.09.

Deplazes P., F. van Knapen, A. Schweiger and P.A. Ovegaauw. 2011. Role of pet dogs and cats in the transmission of helminthic zoonoses in Europe, with a focus on echinococcosis and toxocarosis Vet. Parasitol. 182: 41-53.

Downes F.P. and K. Ito. 2001. Compendium of methods for the microbiological examination of foods American Public Health Association, pp. 473-481. Washington, DC.

El-Shehabi F.S., S.K. Abdel-Hafez and S.A. Kamhawi. 1999. Prevalence of intestinal helminths of dogs and foxes from Jordan. Parasitol. Res. 85: 928-934.

Erdoğrul Ö. and H. Sener. 2005. The contamination of various fruit and vegetable with Enterobius vermicularis, Ascaris eggs, Entamoeba histolyca cysts and Giardia cysts. Food Control. 16: 557-560.

Fallah A.A., K. Pirali-Kheirabadi, F. Shirvani and S.S. SaeiDehkordi. 2012. Prevalence of parasitic contamination in vegetable used for raw consumption in Shahrekord, Iran: Influence of season and washing procedure. Food Control. 25: 617-620.

Gerba C.P. and J.E. Smith. 2005. Sources of pathogenic microorganisms and their fate during land application of wastes. J. Environ Qual. 34(1): 42-48.

Hadi A. 2011. Isolation and identification of intestinal parasites from vegetables from different markets of Iraq. Bull. Iraq Nat. Hist. Mus. 11: 17-25.

Hassan A., H. Farouk and R. Abdul-Ghani. 2012. Parasitological contamination of freshly eaten vegetables collected from loca markets in Alexandria, Egypt: A preliminary study. Food Control. 26: 500-503.

Iournals M. 2014. Determination of parasitic contamination at production phase in deep-redground pepper (Isot) produced in Sanliurfa, Turkey. JAAVA 13: 62-65.

Jamaiah I. and M. Rohela. 2005. Prevalence of intestinal parasites among members of the public in Kuala Lumpur, Malaysia. Southeast Asian J. Trop. Med. Public Health. 36: 68-71.

JOMETEO. 2015. Jordan climate (in Arabic). http://www.jometeo.gov.jo/WeatherReports/9_\%D9\%85\%D9\%86\%D8\%A7\%D8 \%AE\%20\%D8\%A7\%D9\%84\%D8\%A3\%D8\%B1\%D8\%AF\%D9\%86. pdf, 2015.01.21.

Kamhawi S. and N. Hijawi. 1992. Current studies on the epidemiology of unilocular hydatidosis in Jordan and its social implications. Report on Parasitic Diseases of the Middle East8.

Karanis P., I. Sotiriadou, V. Kartashev, C. Kourenti, N. Tsvetkova and K. Stojanova. 2006. Occurrence of Giardia and Cryptosporidium in water supplies of Russia and Bulgaria. Environ Res. 102: $260-271$.

Lanata C. 2003. Studies of food hygiene and diarrhoeal disease. Int. J. Environ. Health Res. 13: S175-S183.

Maraqa A., Z. Amr, L. Rifai and W. Al-Melhim. 2005. An abattoir survey of liver and lung helminthic infections in local and imported sheep in Jordan. Turk. J. Vet. Anim. Sci. 29: 1-2.

Montresor A., D. Crompton, A. Hall, D. Bundy and L. Savioli. 1998. Guidelines for the evaluation of soil-transmitted helminthiasis and schistosomiasis at community level, pp. 1-48. World Health Organization. Division of Control of Tropical Diseases. Schistosomiasis and Intestinal Parasites Unit. Geneva.

Raddad K. 2005. Water supply and water use statistics in Jordan. IWG-Env, International Work Session on Water Statistics. United Nations Statistics Division. Vienna.

Robertson L. and B. Gjerde. 2000. Isolation and enumeration of Giardia cysts, Cryptosporidium oocysts, and Ascaris eggs from fruits and vegetables. J. Food Prot. 63: 775-778.

Robertson L. and B. Gjerde. 2001. Occurrence of parasites on fruits and vegetables in Norway. J. Food Prot. 64: 1793-1798.

Rosen B.H., R. Croft, E. Atwill, S. Wade and S. Stehman. 2000. Waterborne pathogens in agricultural watersheds. US Department of Agriculture, Natural Resources Conservation Service, Watershed Science Institute, Washington, DC.

Shakkoury W. and E. Wandy. 2005. Prevalence of Giardia lamblia infection in Amman, Jordan. Pak. J. Med. Sci. 21: 199-201.

Sharif F. A. 2002. Prevalence and seasonal fluctuations of common intestinal parasites in Khan Younes 1996-2000. Journal of the Islamic University of Gaza 10: 69-79.

Sharrif L., O. Al-Rawashdeh, K. Al-Qudah and F. Al-Ani. 1998. Prevalence of gastrointestinal helminthes, hydatid cysts and nasal myiasis in camels in Jordan. Proceedings of the Third Annual Meeting for Animal Production Under Arid Conditions, Vol. 2: 108-114. United Arab Emirates University.

Slifko T.R., H.V. Smith and J.B. Rose. 2000. Emerging parasite zoonoses associated with water and food. Int. J. Parasitol. 30: 1379-1393.

Uga S., N.T. Hoa, S. Noda, K. Moji, L. Cong, Y. Aoki, S.K. Rai and Y. Fujimaki. 2009. Parasite egg contamination of vegetables from a suburban market in Hanoi, Vietnam. Nepal Med. Coll. J. 11: 75-78. UNRWA. 2015. Camp profiles - Baqảa (Jordan). http://www.unrwa. org/where-we-work/jordan/camp-profiles?field=13, 2015.01.29. World Health Organization (WHO). 2003. Zoonoses and communicable diseases common to man and animals, $3^{\text {rd }}$ ed. Vol. III. Parasitoses. Scientific and Technical Publication No. 580. Washington, D.C. 
